\title{
Employers' Mutuals and Accident Insurance Scheme in Spain: From Rejection to Control and Collaboration (1966-1990)
}

\author{
MARGARITA VILAR-RODRÍGUEZ \\ JERÒNIA PONS-PONS
}

This article discusses the role of employers and their organizations in promoting or hindering social insurance schemes and, ultimately, the welfare state. Unlike most studies that center on countries in periods of democracy, this research focuses on the

\begin{abstract}
(c) The Author(s), 2021. Published by Cambridge University Press on behalf of the Business History Conference. All rights reserved. This is an Open Access article, distributed under the terms of the Creative Commons Attribution licence (http://creativecommons.org/licenses/by/4.0/), which permits unrestricted re-use, distribution, and reproduction in any medium, provided the original work is properly cited.
\end{abstract}

doi:10.1017/eso.2020.71

Published online March 08, 2021

Margarita Vilar-Rodríguez is an associate professor of Economic History at University of A Coruña. Her main research interests cover the history of social insurance, especially health and industrial accidents, as well as wages and wellbeing. She has published extensively in these fields in a historical perspective in major journals, including Business History, Economic History Review, Social History of Medicine, and International Review of Social History and Labor History. Her most recent book (coedited with Martin Gorsky and Jerònia Pons-Pons) is The Political Economy of the Hospital in History (Queensgate, UK: University of Huddersfield Press, 2020). Contact: University of A Coruña, Facultad de Economía y Empresa, Campus de Elviña, s/n, 15071 A Coruña, Spain. E-mail: mvilar@udc.es.

Jerònia Pons-Pons is professor of Economic History at University of Sevilla. Her research focuses on the economic history of insurance, both private and social. With Robin Pearson, she has edited Risk and the Insurance Business in History (Madrid: Fundación MAPFRE, 2020) and with Margarita Vilar-Rodríguez, she has edited Un siglo de hospitales entre lo público y lo privado (Madrid: Marcial Pons Ediciones de Historia, 2018) and several articles in major journals. Together, Pons-Pons and VilarRodrígue have also published a chapter in the anthology edited by Bernard Harris, Welfare and Old Age in Europe and North America (London: Pickering \& Chatto, 2012). Contact: University of Seville, Facultad de Ciencias Económicas y Empresariales, C/Ramón y Cajal, 1, 41018 Andalucía, Sevilla, Spain. E-mail: jpons@us.es

This work was supported by the European Union, the European Regional Development Fund, and Spain's Ministry of Science and Innovation-State Research Agency — for the project entitled "The historical keys of hospital development in Spain and its international comparison during the twentieth century." Number RTI2018-094676-B-I00. 
role of employers, and specifically employers' mutuals, in the development of the industrial accident scheme during the Franco dictatorship in Spain. The institutional elimination of the class struggle, by repressing the working class and prohibiting classbased unions, led to an evolution of the industrial accident scheme and employers' liabilities that revolved around the interrelationship between employers and the state. While employers tried to keep control of the management and low cost of the insurance, the state maintained significant bureaucratic intervention and increased auditing and control. The democratic period that began in 1977 prolonged the structure fostered during the Franco regime and enhanced the power of the mutuals in managing this insurance.

Keywords: Employers; mutuals; industrial accidents; social security; Spain

\section{Introduction}

The classic institutionalist historiography on the construction of the welfare state consolidated the idea that its progress depended on, and was driven by, the struggles of workers and progressive movements. In this process, employers would have maintained a stance, in general, of confrontation and little cooperation in its development. ${ }^{1}$ In recent decades, some authors who have reflected on this idea reached the conclusion that it was not so in all cases. Accordingly, there is defense of the thesis that some employers were interested in social reform as a mechanism for directing and controlling the evolution of the labor market and, on occasion, they united with labor leaders to create cross-class alliances and to support the reformers promoting social legislation. ${ }^{2}$ This process did not develop uniformly across countries and historical contexts, which led to the existence of different national welfare state models. One important study in this respect analyzed the historical evolution of social insurance policies in Sweden and the United States in the 1930s, a period that corresponded with a phase

1. The concept of welfare state and its different historical manifestations in accordance with countries' socio-cultural conditions are already outlined in Wilensky and Lebeaux, Industrial Society. The best-known classification in the literature on the three basic welfare state models can be found in Esping-Andersen, Three Worlds. With regard to the Spanish case, the particular features of the process of creating a welfare state can be found in Comín Comín, "Los seguros sociales," and in González Madrid and Ortiz, El estado del bienestar.

2. There are noteworthy works that maintain that many social policies were created through an alliance of class interests. For Sweden and the United States, see Swenson, Capitalists against Markets; for Germany, see Swenson, "Good Distribution." 
of significant development in the social welfare programs of both countries. This analysis concludes that Swedish employers, in order to address a chronic shortage of labor and also to keep wages low, cooperated with trade union leaders in exchange for achieving greater labor security and maintaining greater unity and a more stable leadership. This alliance was also supported by the Swedish Social Democrats. American capitalists, for their part, had different labor market strategies depending on the economic sector. Thus, employers in monopolistic sectors supported segmentation and used high wages to keep the unions at bay. Simultaneously, they also backed social legislation to counter fierce competition during the Depression. This thesis essentially argues that during the Great Depression, American employers were more willing than their Swedish counterparts to back government reforms to ease stiff competition. However, these roles were reversed in the 1950s. Now it was Swedish employers who backed their government in developing social benefits to counter the growing practice of some private companies stealing workers from employers that continued paying low wages.

Peter A. Swenson is working on a theory that moves between the institutionalism that ignores the role of employers and the instrumentalists who consider the role of capitalists to be crucial in this process. Isabela Mares's work moves along similar lines. ${ }^{3}$ She presents theoretical and empirical descriptions of the role of employers in the development of Social Security, especially in schemes such as industrial accidents and unemployment. Mares focuses on an empirical study of cases of social policy reforms in France and Germany and examines the interests and preferences of employers in this regard. She found that employers do not always act in the same way. Associations dominated by large firms, with more skilled workforces, opt for contributory or private social insurance schemes while those dominated by small enterprises oppose these initiatives. In terms of accident rates, highrisk firms favor highly redistributive social insurance policies while low-risk firms endorse insurance policies based on actuarial criteria. She also writes of the existence of cross-class alliances to promote social legislation, and argues that preexisting social policy structures condition the strategies of employers and unions when it comes to introducing new social policies.

However, most of these studies are set within the context of democratic countries, where unions interact more or less freely with employers' associations to create alliances with social reformers. ${ }^{4}$

3. Her basic ideas can be seen in Mares, Politics of Social Risk; Mares, "Sources of Business"; Mares, "Distributional Conflicts," 70-71.

4. The few works available demonstrate the difficulties that exist to make this comparison and focus on the study of democracies, taking for granted the existence 
There is very little literature addressing the role of employers and their associations under dictatorial regimes where free unions are banned, and governments-with objectives of propaganda and social pacification-introduce social insurance schemes as part of their social policies. The current literature on the management of industrial accident insurance focuses on comparing industrial accident rates between countries or the legislation in force in each country. ${ }^{5}$

Therefore, our empirical study of the evolution of the industrial accident scheme in the Spanish case contributes to the international debate on the role of employers in the development of social insurances in a little studied context of dictatorship, where workers lack legal mechanisms to exert pressure and where employers influence governments to ensure that their interests prevail. It also demonstrates how such a model can be inherited, perpetuated, and continue to influence society even after a democratic period is initiated.

The Law on Industrial Accidents—the Dato Law—passed in Spain in 1900, established the liability of industrial employers for the accidents of their workers. It was passed against a backdrop of social reformism during which tenuous attempts were made to improve the working conditions of employees. ${ }^{6}$ Most Spanish employers were reluctant to accept an extension of this law and the establishment compulsory insurance to cover accidents. Employers were also opposed to including occupational diseases within the category of industrial accidents. ${ }^{7}$ Several bills were presented in the Spanish Parliament between 1919 and 1921 to extend the law to agricultural workers, but all failed to

of basic and labor rights and the fact that workers have a certain negotiating capacity. For more on these aspects and the difficulties to make comparisons in this area, see Philipsen, "Industrial Accidents and Occupational Diseases," 194-196.

5. In this respect, a legislative summary of different countries can be found at Prevención de Riegos Laborales, "Reino Unido,” https://prl.ceoe.es/informacion/ prl-en-el-mundo/reino-unido/. Also see Foment del Treball Nacional, Guía de equivalencias de Prevención de Riesgos Laborales, where the legislation on the prevention of occupational risks can be compared, http://prl.foment.com/admin/uploads/docs/ 20150206100433.pdf.

6. During the first decade of the twentieth century, 531 social regulations were passed, including 20 laws, although they had little impact because they were too difficult to implement. See Cabrera, El poder de los empresarios, 156. The Commission for Social Reforms had been created in 1890, which carried out important statistical work by compiling data on the living conditions of workers and the most vulnerable sectors of the population. It was replaced in 1903 by the Institute of Social Reforms (1903-1924). For further details, see Palacio, La institucionalización. For more on the development of social insurance schemes in Spain, see Cuesta, Los seguros sociales; Montero, Orígenes y antecedentes; Samaniego, La unificación de los seguros; and Pons-Pons and Silvestre, Los orígenes.

7. One of the most controversial issues was considering a hernia as an occupational injury. Bengoechea, Patronal catalana. 
progress. ${ }^{8}$ The first significant change took place in 1922 with the passage of Matos Law, with the most notable innovation being a 25 percent increase in the amount of temporary allowances for injured workers. The reform also set up a special guarantee fund, although for budgetary reasons it was not put into force until $1933 .^{9}$

Industrial employers agreed to financial responsibility for compensating and paying the healthcare coverage of injured workers but strongly opposed compulsory insurance. Conservative and Liberal governments during the Restoration, and later during the Primo de Rivera dictatorship (1923-1930), gave into pressure from employers, although the politicians encouraged them to voluntarily carry insurance. They promoted the creation of employers' industrial accident mutuals, which, through associationism, helped spread the idea of accident insurance. ${ }^{10}$ This was accomplished when private insurers as well as commercial insurance companies started to sell this insurance. In 1910, the market share of employers' mutuals was only 5.67 percent of the entire accident branch, a percentage that gradually increased to 15 percent by $1932 .{ }^{11}$ From 1900 to 1936, the mutuals managed this insurance activity in the interests of their membersthat is, the employers who made up the mutuals' boards of directors, on which workers had no representation. Under these circumstances, employers met their legal responsibilities at the lowest possible cost by keeping premiums low. On the one hand, this strategy led to confrontations between employers' associations and commercial insurance companies over the offer and pricing of policies. On the other hand, it allowed members to meet a main objective of creating medical, clinical, and hospital infrastructure to treat their injured workers as quickly and cheaply as possible. Moreover, these mutuals had the appeal of providing members with annual rebates in the event of year-end profits (which was almost always the case). It should be noted that the rebates were part of the premium that the insurer (i.e., the mutual) returned to the insured (i.e., the employer who paid the premium). If the mutuals spent little (especially on prevention and coverage), they got back some of the money raised through the premiums; that is, a percentage of this money was reimbursed to employers in the form of these rebates, which effectively reduced the price of the insurance premium. This rebate was quite

8. Conferencia de Seguros Sociales, Conclusiones, 60-65. For the presentation of the bill of 1919, see Gazeta de Madrid (1900-1936), February 20, 1919, https:// www.boe.es/buscar/gazeta.php.

9. Jordana, La Caja Nacional, 14.

10. Prat and Molina, "State Corporatism," 208-210.

11. Anuario Guía del Asegurador, 1935, LIX. 
common in the leading mutuals of this period, as revealed by their annual reports. ${ }^{12}$

For its part, the state carried out inadequate control of safety in the workplace. The Ministry of Labor was created by Royal Decree of May 8, 1920, and incorporated the Institute of Social Reforms and the Labor Inspection Service. This service was structured across twelve regions. However, there were only ten inspectors at the regional level, sixtythree inspectors at the provincial level, and sixty-one ancillary staff and clerks. The extremely limited staff of the Labor Inspection Service in 1923 had to deal with far more serious infringements than violations of safety and hygiene measures in the workplace, such as abuses of child labor, the length of the working day, and not keeping Sunday as a rest day. ${ }^{13}$ In 1924 , only 7.87 percent of the infractions found by this supervisory body related to noncompliance with safety and hygiene measures in the workplace. The Spanish political institutions, for their part, collaborated with employers' interests by maintaining lower compensation rates than in neighboring countries and failing to extend liability for workers' accidents to agricultural employers, despite bills presented in Parliament. Under these circumstances, employers' mutuals developed slowly but steadily, especially in the country's more industrialized regions-such as Catalonia, the Basque Country, and Madrid -which also had the highest percentage of wage laborers. ${ }^{14}$

The most significant change during this period took place during the so-called reformist biennium (1931-1933), after the proclamation of the Second Republic (1931-1936). During the biennium), agricultural employers were made responsible for covering their workers. Therefore, from the reformist biennium forward, both agricultural and industrial employers had to carry insurance policies for their workers. This change had two major consequences. First, employers' mutuals proliferated. Whereas only 42 industrial mutuals had been created and authorized in Spain before 1931, there were 155 by December 1935; and while there were no mutuals in the agricultural sector before 1931, there were 78 by $1935 .{ }^{15}$ Local and provincial agricultural employers'

12. Mutuas 27A y 26B, Dirección General de Previsión, 1885-1963, La Metalúrgica. Informe a la Dirección General de Previsión, 1942, Archivo del Ministerio de Trabajo, Migraciones y Seguridad Social de España (hereafter MITRAMISS).

13. Cuadro orgánico de Inspectores, Auxiliares y escribientes del Trabajo en 31 de diciembre de 1923. Instituto de Reformas Sociales, Memoria General de la Inspección del Trabajo correspondiente año 1923.

14. For further information on the coefficients of industrialization in the different regions of the country at this time, see Germán Zubero et al., Historia económica regional. Furthermore, the lists of active mutuals published periodically in the Official State Gazette verify this greater concentration. See, for example, Gazeta de Madrid, January 11, 1936.

15. See Pons-Pons, “Employers and Industrial Accident Insurance,” 220. 
mutuals were required to directly cover the healthcare of injured agricultural workers. Thus, agricultural insurance companies that could only offer policies that covered compensation were marginalized. The same was true for industrial insurance companies starting in 1932. This rocketed the creation of mutuals linked largely to national and regional employers' associations. Their market share was 19.47 percent in 1933 and 36.08 percent in $1934 .{ }^{16}$ This obligation to cover employees was effectively turned into an opportunity. The second consequence was that employers who sat on the boards of directors of these mutuals fully committed to the private insurance business and diversified their activity by adding fire, marine, and life insurance. Thus, employers' mutuals gave rise to large insurance mutuals with significant weight in the insurance industry in the second half of the twentieth century. However, prevention of worker injuries and rehabilitation if they occurred were major issues that were ignored. This is evidenced by the fact there is no trace of investment in these areas in the minutes of board meetings or in memoranda and balances. ${ }^{17}$

The political, economic, and social divisions ensuing from the Spanish Civil War (1936-1939) gave rise to a new historical period for employers' industrial accident mutuals, which continued until 1966. Like many other company and welfare mutuals, boards of directors and management boards were subject to political purges, and were monitored and supervised by the different bodies created by the dictatorship of the new regime. ${ }^{18}$ During the period of autarky, there were few changes to insurance practices, the exception being the creation of the obligatory reinsurance of industrial accidents in 1942. The management of insurance continued to be shared between private hands (that is, employers' mutuals and insurance companies) and the Caja Nacional de Accidentes de Trabajo (CNAT; National Industrial Accident Insurance Fund, founded in 1933). The minutes of the CNAT show that the obligatory nature of insuring the workers of public bodies, and the legal impossibility of rejecting any policy, made a higher accident claim rate inevitable. Thus, for example, according to data for 1949, the comparison between the claims ratio of the CNAT and the mutuals and private commercial insurance companies was as follows: CNAT, 81.24 percent; L’Abeille, 51.9 percent; Mutua General de Seguros, 45.57

16. Anuario Guía del Asegurador, 1935, LIX.

17. The little importance given to prevention during this period can be seen in the works of Silvestre, "Wage Compensation"; Silvestre, "Workplace Accidents"; Silvestre and Pons-Pons, "El seguro de accidentes."

18. One example is the Mutua General de Seguros, leader in the industrial accidents branch, which was obliged to purge its managing director and some of the staff. See Libro de actas del Consejo de Administración, núm, 2, Acta de 1 de marzo de 1939, Archivo de Mutua General de Seguros. 
percent; and Mutua Regional de Accidentes del Trabajo, 48.8 percent. ${ }^{19}$ On the one hand, the CNAT had to pay commissions to their agents, as was also true for the private insurance of mutuals and commercial companies, yet it could not apply risk selection, whereas private insurers could. On the other hand, the employers' mutuals intensified a strategy that originated in the market competition of the 1930s. They diversified their activity, as mentioned earlier, by moving into other lines of private insurance, both in the interest of increasing their profits and out of fear of the nationalization of the industrial accident branch. The executives of the mutuals played a key role in this process. It should also be noted that the division between mutuals disappeared in 1955, when many agricultural mutuals were absorbed into industrial mutuals.

Collaboration between the mutuals and the state was critical in the phenomenon of diversification. In 1942, the introduction of Seguro Obligatorio de Enfermedad (Compulsory Sickness Insurance) and the state's lack of medical personnel and clinical infrastructure favored the employers' mutuals, which had already created a healthcare network to deal with workers' accidents. This enabled them to become members of the collaborating bodies of state sickness insurance starting in 1945. This step was taken by the most important employers' mutuals, along with mutuals specifically created by commercial insurance companies to participate in this new business. They were involved in the coverage and management of Compulsory Sickness Insurance until 1955. Nevertheless, their balance sheets suffered from multiple problems, including the progressive reduction of the percentage of premiums they were allowed to discount to cover management costs, the rise in pharmaceutical expenses, and the extension of treatments and specialties covered by insurance. Deficits increased and as a result, after a decade of collaborating with the Compulsory Sickness Insurance, many employers' mutuals did not renew their agreements. A few continued their collaboration until the passage of the Basic Law on Social Security in 1963, which ended the collaborative management system, but not other types of agreements with the private sector, such as agreements with hospitals (for example, to have a greater number of beds available). ${ }^{20}$

During the first period of the Franco dictatorship, employers' mutuals were subject to extensive bureaucratic control by the Accident Insurance Inspection Service, which demanded continual documentation, such as required monthly fillings of forms at provincial and

19. Ponencia sobre la C.N.S.A.T, Actas 1949, Actas del 10 al 29, Archivo del Instituto Nacional de Gestión Sanitaria, Ministerio de Sanidad.

20. For more on the management and funding of the compulsory sickness insurance, see Pons-Pons and Vilar-Rodríguez, El seguro de salud, 119. 
national levels, with consequent penalties for noncompliance. However, state control over the coverage of these mutuals' workers was, in fact, fairly lax. The mutuals still did not invest significantly in prevention or rehabilitation, and the accident figures declared by some mutuals were surprisingly low. Nonetheless, the declared balance sheets of many mutuals show a substantial increase in annual profits that afforded regular rebates of an average of 20-25 percent of premiums collected, even reaching 35 percent in some cases and years. ${ }^{21}$ Meanwhile, recognized occupational diseases were limited to silicosis, and the number of afflicted workers compensated was fairly insignificant. Moreover, of the workers who were entitled to a monthly income for permanent incapacity, nearly none had their applications approved for a lump-sum payment instead. This denial occurred even though the workers were entitled by law to receive a lump sum rather than monthly income, that latter of which was insufficient to live on. During this period, even though employers' mutuals were subject to exhaustive bureaucratic control, they also faced little effective control concerning their obligations on the safety of their workers and efforts to reduce the accident rate. This ended in the 1960s when questions were raised about their role and the need to incorporate social insurance into a Social Security project, which was being developed. In principle at least, private insurance, both mutuals and commercial insurance companies, were excluded from the project.

\section{Fighting for Control of the Industrial Accident Scheme} (1966-1975)

Implementation of the Basic Law on Social Security, passed in 1963, enabled employers' mutuals to consolidate their business in the industrial accident branch, without competition from the commercial companies. It also ratified their role as private collaborating bodies in state management of Social Security. ${ }^{22}$ The new framework did not come into force until April 30, 1966. The commercial companies received what was more or less negotiated compensation with passage of

21. Memorias anuales de La Metalúrgica (ramo de accidentes de trabajo), 27A y 26B, Dirección General de Previsión, Mutuas 1885-1963, La Metalúrgica, 5 legs, MITRAMISS.

22. Full Text I, of Law 193/1963, of December 28, establishing Social Security, (Boletín Oficial del Estado [BOE] Official State Gazette), April 22, 1966, 96, 4784-5. In particular, the collaboration of the employers' industrial accident mutuals in the management of Social Security was stipulated in the General Regulation approved by Decree 1563/1967, BOE, July 17, 1967, no. 169, 10101-9, Boletín Oficial del Estado (1936-1990), https://www.boe.es/. 
compulsory automobile insurance, which became an important line of business for private insurance. ${ }^{23}$ As noted in the dates just given, three years of arduous debate ensued between publication of the law and its implementation. There may have been outside influences in this process when there was greater openness and a shift in Spain's economic policy. However, we think that the most influential factor was the serious financial problems of the system of social insurances in effect up to this time, especially in health insurance because of its unsustainable deficits. $^{24}$

During this period, before insurance was nationalized, the employers who made up the boards of directors of the mutuals exerted political pressure to continue managing industrial accident insurance. Their pressure in the negotiation process is an example of what Sánchez Recio termed "capitalism understood as a network of interests," where those with greater lobbying capacity (i.e., employers) obtain a framework more favorable to their interests. This would have been the normal modus operandi under the Franco dictatorship. ${ }^{25}$ However, the seventeenth provision of Basic Law on Social Security, which dealt with the management of Social Security, established that the mutualidades laborales (workers' mutuals) would be responsible for insuring against industrial accidents and occupational diseases. It should be clarified here that these mutuals had been promoted by the Falangist Minister of Labor José Antonio Girón as part of the system of social welfare that was obligatory but supplementary to the compulsory old age and invalidity insurance created in 1947. With the 1963 law, these worker mutuals were authorized to manage industrial accident insurance, which competed with the employers' mutuals. The legal standing of the workers' mutuals and their way of achieving an economicfinancial equilibrium was never made completely clear, but during the first twenty years of their existence, they granted pensions that varied by labor sector, which introduced an element of discrimination. ${ }^{26}$ The exclusion of insurance companies from the seventeenth provision was quite specific, yet there was no explicit reference to employers' mutuals. This opaqueness set up a confrontation between

23. For more details, see Pons-Pons, "La gestión patronal,” 143-144.

24. For further details, see Pons-Pons and Vilar-Rodríguez, El seguro de salud, 208; and Vilar-Rodríguez and Pons-Pons, "La Ley de Bases de la Seguridad Social," $145-149$.

25. For further insights into this concept, see Sánchez Recio, "El franquismo como red de intereses," 17. On the other hand, on the negotiations prior to the passage of the Basic Law on Social Security, see Hernando de Larramendi, Así se hizo MAPFRE.

26. An economic and financial study of these entities can be found in Redecillas, El mutualismo. For more details on their complex functioning, see Pons-Pons and Vilar-Rodríguez, El seguro de salud, 145-167. 
the workers' mutuals (supported by the Falange government) and the employers' mutuals (supported by employers). This clash was eventually resolved by the Minister of Labor Romeo Gorría (1962-1969), who was close to the Opus Dei, in favor of the employers. We note here that Opus Dei, defined as a prelature of the Catholic Church, is considered a political "family" (along with Catholics, Falangists, monarchists, etc.) that included the Franco dictatorship in its final decades. After the government crisis of 1956, new ministers closely related to Opus Dei gained political weight in the ruling circles of the dictatorship. ${ }^{27}$

The Order of April 27, 1966, implementing the Basic Law on Social Security, did include the employers' industrial accident mutuals as collaborators in the administration of the insurance. According to Hernando de Larramendi, director of the employer's mutual MAPFRE, there was a great deal of tension and long meetings between the Dirección General de Previsión (Directorate General for Welfare) and the representatives of the employers' mutuals to establish the legal framework. ${ }^{28}$

This victory for the employers' mutuals provided them with an opportunity to increase their market share in industrial accident insurance, the premiums of which they had thus far shared with the insurance companies. In 1961 the distribution of these total premiums was divided as follows: employers' mutuals at 43.08 percent, national insurance companies at 46.92 percent, and foreign insurance companies at 10 percent. ${ }^{29}$ The mutuals had to tackle two major challenges in the following years: one was to separate their operations from industrial accident insurance, and the other was being subjected to greater oversight and auditing of their accounts by the Ministry of Labor. This gave rise to serious tension with the state, as the mutuals had historically kept control over the management of the insurance premiums of associated employers without the need for any agreement with workers or public accountability. Even so, in a dictatorship that was favorable to their interests, the employers still enjoyed great freedom in the labor market and the workers had few basic rights. The Ley de Unidad Sindical (Law of Trade Union Unity) of 1940 converted the Fascist political party, La Falange, into the only organization authorized to handle labor conflicts. ${ }^{30}$ Although this vertical syndicate, or "union," performed an important function in the dictatorship's repressive machinery, it was

27. For more on this organization, see Barrera, "El Opus Dei”; Muñoz, "Después de la tormenta."

28. Hernando de Larramendi, Así se hizo, 291.

29. Data from Velarde, de Guindos and Lázaro, “Aspectos estadísticos,” 20.

30. The Ley de Unidad Sindical can be found in the BOE, January 31, 1940. For more details on the functioning of the vertical "trade union," see Sánchez Recio and Nicolás, "Sindicalismo vertical." 
employers within their own companies who exercised effective control over their workers. ${ }^{31}$ This legal scenario destroyed the rest of wage earners' limited abilities either to protest or negotiate. Under these conditions, employers' main concerns were guaranteeing the availability of cheap labor and retaining management of low-cost accident insurance. This enabled them to receive rebates every financial year while their investments in prevention and rehabilitation were kept to an absolute minimum. ${ }^{32}$

The legislation implemented in 1966 established four prerequisites for the constitution and functioning of employers' mutuals. ${ }^{33}$ As mentioned, the employers' mutuals continued managing industrial accident insurance, but with sharp oversight by the Ministry of Labor. The first prerequisite was to have a mutual's territorial scope limited by locality, district, or province of the national territory (or a larger territorial scope with specific Ministry of Labor authorization). This measure made it easier for the state to supervise and monitor the activities of employers' industrial accident mutuals via the Ministry of Employment and Social Security. These mutuals were also subject to control by the Labor Inspection Service and the Health Services Inspectorate, although a system of employer self-government was maintained as stipulated in the statutes of each company.

The second prerequisite was that these mutuals limit their activity exclusively to insuring industrial accidents and occupational diseases, and this had to be independent from any other of their business dealings. This legal separation between the industrial accident branch and the rest of their private insurance activity did not cause problems for smaller employers' mutuals with only local or provincial scope, and their other insurance activity was minimal or nonexistent anyway. However, this caused serious problems for the large national mutuals by creating an almost traumatic process that lasted for years. These mutuals had to divide up their property and assets, decide the future of their staff (some remained with the employer's mutual and others were incorporated into the resulting insurance mutual), and over time they even had to differentiate their business names. They successfully delayed this process for a few years. Larger mutuals continued to share buildings and common areas, managerial and administrative personnel, and even the same members on the respective boards of directors of

31. Part of the historiography is that real power within the company was in the hands of the "caudillo-businessman" (caudillo usually means military leader or political boss, and Franco was known as "El Caudillo”). See, for example, Babiano, Paternalismo industrial, 56-59.

32. These can be seen in the reports published by the mutuals at this time, in 27A y 26B, Dirección General de Previsión, Mutuas 1885-1963, MITRAMISS.

33. BOE, April 22, 1966, no. 96, 4862. 
the accident insurance branch and insurance for other risks. ${ }^{34}$ Because the transition was being dragged out, in 1969 the Ministry of Labor demanded separation, forcing these mutuals to finalize the process. Two major employers' mutuals in Spain at this time-Mutua General de Seguros and MAPFRE, finally split up their insurance businesses. The former gave rise to Mutua General, and the latter created an employer's mutual under the business name of FREMAP. Both spinoffs specialized in insuring against industrial accidents. ${ }^{35}$

The third prerequisite was that the mutuals (1) make a compulsory deposit as a guarantee to cover their payment obligations, and (2) limit their administrative expenses not to exceed 10 percent of the volume of their revenue. ${ }^{36}$ The fourth prerequisite occurred with new legislation that required each mutual to employ at least ten employers and two thousand workers and to have the ability to pay a minimum volume of Social Security contributions to cover industrial accidents, as established in the regulations. Thus, for the first time, these entities experienced state intervention in their internal management.

The state retained the not-for-profit principle, which was initially compatible with the payment of rebates, as these were not considered as profits. Nevertheless, rebates were limited to 20 percent of the surplus, and only after the reserves established by the regulations had been met (Table 1). The remaining 80 percent of rebates had to be reimbursed to Social Security, except when there had been a prior application to use part of this amount as investments in rehabilitation centers. ${ }^{37}$ The employers' mutuals, faced with the possible loss of the majority of their surpluses, for the first time showed an interest in the rehabilitation of injured workers. The retraining of disabled workers had been mentioned in the law as early as 1933, and the state had created centers such as the Institute for the Professional Retraining of the Disabled in the Workplace in 1924 and the Work Clinic of the National Welfare Institute in 1933. This was also addressed in the Law on Industrial

34. Libro del consejo de administración, núm. 3, Acta de 20 de Mayo de 1968, Archivo de Mutua General de Seguros.

35. García Ruiz and Caruana, "Historia de una Mutua Patronal”; Fábregas, Los primeros 100 años.

36. Order of December 28, 1966, determined the amount of the deposit and administrative expenses of the employers' mutuals that collaborate in the management of industrial accidents and occupational diseases within the General Social Security System. BOE, December 30, 1966, no. 312, 16497-8.

37. Article 8 of the General Regulation on collaboration in the management of Social Security, approved by Decree on July 6, 1967, permitted mutuals to construct and establish, in a common ownership regime, facilities and services for professional recovery and rehabilitation up to a cost of 80 percent of the surplus of their management. BOE, July 17, 1967, no. 169, 10101-9. 
Table 1. Surpluses in the management of industrial accident insurance, workers' mutual, and employers' mutuals (in millions of current pesetas)

\begin{tabular}{lr}
\hline Year & Volume of 20\% of surpluses \\
\hline 1966 & 134.4 \\
1967 & 138.5 \\
1968 & 508.8 \\
1969 & 360.8 \\
1970 & 338.4 \\
1971 & 236.7 \\
1972 & 290.5 \\
1973 & 238.7 \\
1974 & 161.7 \\
1975 & 535.6 \\
\hline Source: Datos de las cuentas de gestión de las Mutualidades Laborales y las Mutuas Patronales (data \\
from the management accounts of the Labor Mutualities and the Employers' Mutual Societies), in \\
Ministerio de Trabajo, Libro Blanco, 447-499.
\end{tabular}

Accidents of 1956, but there was no adequate development of rehabilitation in Spain until the 1960s. ${ }^{38}$

This regulatory change persuaded those running the main employers' mutuals to promote important joint projects in 1968, such as creating intermutual rehabilitation and prevention centers and healthcare centers throughout national territory. For example, under this law, authorization was given to eighteen mutuals in 1968 to establish a recovery and rehabilitation center in Levante. Meanwhile, in the province of Biscay, four mutuals came together to create the Centro Intermutual Vizcaíno de Prevención, Recuperación y Rehabilitación "Archanda" (Intermutual Center for Prevention, Recovery and Rehabilitation “Archanda”). Also in 1968, the Centro Mutual para la Rehabilitación de Accidentados del Trabajo de Barcelona (Mutual Center for the Rehabilitation of Injured at Work in Barcelona) was created, funded by forty-five mutuals. It opened in $1974 .{ }^{39}$ The promotion of these intermutual centers encouraged the mutuals to collaborate at the regional level.

There was a progressive loss of the autonomy that these entities had enjoyed in the preceding decades. This was exacerbated with passage of Ley de Financiación y Perfeccionamiento de la Acción Protectora del Régimen General de la Seguridad Social (Law on the Financing and Improvement of the Protective Action of the General Social Security Scheme) in 1972. ${ }^{40}$ This law provided that the premiums of industrial accident insurance collected by employers' mutuals, which to date had been the exclusive ownership of employers, was now considered

\footnotetext{
38. See Porras, "La medicina y los seguros,” 409-410.

39. Pons-Pons, "La gestión patronal," 134.

40. BOE, June 22, 1972, no. 149, 11174-7.
} 
Social Security contributions. This change led to the mutuals becoming collaborating bodies on Social Security, although legally they were still private voluntary employers' associations. ${ }^{41}$

This law brought more limitations to the mutuals' management and more mechanisms for the Ministry of Labor to monitor, control and supervise them. This affected the mutuals' constitutional and operational guidelines as well as their economic and financial systems. Consequently, the mutuals' income via the industrial accident premiums (paid for by associated employers) and the movable and immovable property in which this income was invested were now all Social Security assets. This occurred within a framework in which members were now prohibited from keeping economic gains of any kind, which was the opposite of previous decades. Additionally, the mutuals were responsible for the costs arising from the economic provisions for professional contingencies; they had to contribute to prevention and rehabilitation services; and they had to cover administrative costs within the limits established by the government.

By the end of the dictatorship in 1975, the income from employers' contributions (i.e., premiums) was close to thirty thousand million pesetas. ${ }^{42}$ This is because the private sector was responsible for paying for two-thirds of the management of the contingencies arising from professional risks, while the remaining third was paid by public bodies. The legislation implemented in 1966 had provided that the workers of public territorial entities (i.e., state, province, or municipality), public companies, or companies considered to be of national interest could not belong to an employers' mutual to cover the risk of industrial accidents or occupational diseases. Instead, they had to join the corresponding Mutua Laboral (workers' mutuals). ${ }^{43}$ As related to Social Security, on the one hand, employers' mutuals' importance was now greatly reduced, with their revenues barely accounting for 5 percent of total contributions to the system. On the other hand, they remained key figures because of their overall management of the contingencies arising from professional risks.

It should, however, be asked whether the mutuals complied with all the requirements demanded by the Basic Law of 1963. As noted earlier, mutuals delayed separating their management of industrial accident insurance from their other lines of business for as long as possible. As for administrative costs, we can affirm that in 1975 these exceeded 10 percent of the mutuals' total revenue, the limit established by the

41. See Ministerio de Trabajo, Libro Blanco, 440-450.

42. Data from Ministerio de Trabajo, Libro Blanco, 441.

43. BOE, November 29, 1966, no. 285, 14985-92. 
Table 2. Number of employers' mutuals operating in Spain, 1966-2007

\begin{tabular}{lrrr}
\hline Year & Number & Year & Number \\
\hline 1966 & 292 & 1988 & 122 \\
1967 & 181 & 1989 & 113 \\
1968 & 176 & 1990 & 97 \\
1969 & 192 & 1991 & 85 \\
1970 & 192 & 1992 & 59 \\
1971 & 189 & 1993 & 43 \\
1972 & 186 & 1994 & 39 \\
1973 & 186 & 1995 & 36 \\
1976 & 187 & 1996 & 34 \\
1977 & 185 & 1997 & 32 \\
1978 & 185 & 1998 & 30 \\
1979 & 182 & 1999 & 30 \\
1980 & 177 & 2000 & 30 \\
1981 & 176 & 2001 & 29 \\
1982 & 171 & 2002 & 29 \\
1983 & 168 & 2003 & 29 \\
1984 & 162 & 2004 & 29 \\
1985 & 150 & 2005 & 28 \\
1986 & 136 & 2006 & 28 \\
1987 & 131 & 2007 & 22 \\
\hline 50195 & & & \\
\hline
\end{tabular}

Sources: Authors' compilation. For 1966-1973, based on números extraordinarios de estadística 1971 and 1974 (extra numbers with statistical data 1971 and 1974), Revista del Sindicato Nacional del Seguro. For 1974-2000, based on Valenzuela, Protagonistas. From 2001-2007, based on the statistical database of the Association of Industrial Accident Mutuals, https://www.amat.es/.

law. ${ }^{44}$ Moreover, the mutuals widely used subsistence expenses to compensate for the legal prohibition against profit sharing.

The first wave of closures, takeovers, and mergers of employers' mutuals occurred in 1966, leading to a reduction in their numbers. Those that could not or did not want to adapt to the new legal requirements disappeared. In 1966 the fragmented sector comprised 292 authorized entities, which plummeted to 181 in 1967 (Table 2). This means that more than one hundred employer mutuals were liquidated in just one year because of their low level of activity or inability or unwillingness to meet the new regulatory requirements. The number stabilized during the 1970s, but via mergers and takeovers. And the registration of new employers' mutuals slowed drastically, with only a dozen new mutuals starting between 1966 and 1973. By 1973, the twenty leading employers' mutuals accounted for more than 60 percent of premiums. The reduction of more than a hundred entities (plus all the mergers and acquisitions) and the elimination of the competition from private insurance enabled the larger employers' mutuals offering industrial accident insurance to increase their revenue. 
Table 3. Industrial accident insurance, contributions and benefits managed by employers' mutual, 1969-1973 (in millions of pesetas)

\begin{tabular}{rrrr}
\hline Year & Amount of contributions & Benefits & Benefits as a \% of contributions \\
\hline 1969 & $10,831.91$ & $5,363.45$ & 49.51 \\
1970 & $12,399.70$ & $6,320.09$ & 50.96 \\
1971 & $14,323.13$ & $7,318.92$ & 51.09 \\
1972 & $17,145.76$ & $8,267.99$ & 48.22 \\
1973 & $21,230.34$ & $10,532.48$ & 49.61 \\
\hline
\end{tabular}

Source: números extraordinarios de estadística 1974 (extra numbers with statistical data 1974), 12, Revista del Sindicato Nacional del Seguro.

Even with this smaller number, there remained a constellation of entities. Additionally, while employer mutuals resisted state control in order to keep more profits, they proliferated unprofitable or costineffective healthcare facilities and services. Contributions doubled between 1969 and 1973, but so did the payouts of benefits; even so, the ratio remained around 50 percent, which meant ample financial margins (Table 3).

In short, in Spain, the progressive incorporation of employers' industrial accident mutuals as collaborators in Social Security was not a result of hashed-out agreements between employers and workers. This type of working alliance among classes and interests, which is observed in other countries, did not work in Spain because of a dictatorial framework in which workers had no voice while employers had great leeway to act as they wished within a political status quo aligned with their interests. Consequently, the power struggle that ensued was between the state and employers. As the state weaved an ever tighter legislative framework for greater control and oversight, the mutuals fought to keep control of their business for as long as possible.

\section{Employers' Mutuals under Democracy (1976-2000)}

The employers' mutuals had a decision to make: stay in control or keep their business afloat. After Franco's death in 1975, Spain's so-called transition to democracy started. The early years were largely dedicated to enacting copious legislation aimed at restoring rights and freedoms after almost forty years of dictatorship. The new general regulation on employers' industrial accident mutuals to collaborate in the management of Social Security, passed in 1976, consolidated the measures established in the legislation of $1963 .{ }^{45}$ This new regulation introduced

45. Royal Decree 1509/1976, of May 21, approving the General Regulation on the collaboration of Employers' Industrial Accident Mutuals in the management of Social Security. BOE, July 2, 1976, no. 158, 12941-8. 
Table 4. Percentage of workers as members of trade unions, 1950-1990

\begin{tabular}{lrrrrrrrr}
\hline & 1950 & 1960 & 1965 & 1970 & 1975 & 1980 & 1985 & 1990 \\
\hline Austria & 62 & 67.88 & 66.16 & 62.75 & 58.99 & 56.72 & 51.60 & 46.93 \\
Belgium & & 41.46 & 39.86 & 42.07 & 51.86 & 54.10 & 52.43 & 53.94 \\
Denmark & 56 & 56.91 & 58.20 & 60.30 & 68.87 & 78.61 & 78.16 & 75.34 \\
France & & 19.65 & 19.47 & 21.69 & 22.15 & 18.28 & 13.61 & 9.99 \\
West Germany & 38 & 34.67 & 32.89 & 32.03 & 34.58 & 34.90 & 34.67 & 31.22 \\
Ireland & 42 & 43.09 & 45.83 & 50.58 & 52.58 & 54.28 & 51.47 & 48.53 \\
Italy & 44 & 24.68 & 25.50 & 36.97 & 48.05 & 49.58 & 42.49 & 38.81 \\
Netherlands & 43 & 40.02 & 37.39 & 36.50 & 37.76 & 34.78 & 27.72 & 24.57 \\
Spain & & & & & 18.30 & 18.70 & 10.23 & 12.54 \\
Sweden & 67 & 72.08 & 66.29 & 67.75 & 74.46 & 77.96 & 81.29 & 79.42 \\
United Kingdom & 45 & 38.89 & 38.72 & 43.05 & 42.07 & 49.74 & 44.26 & 38.18 \\
United States & 24.2 & 30.90 & 28.17 & 27.43 & 25.29 & 22.06 & 17.45 & 15.45 \\
\hline
\end{tabular}

Source: Authors' compilation based on Historical Data Visualization, "Trade Union Membership," Harvard Business School website, https://www.hbs.edu/businesshistory/courses/resources/historicaldata-visualization/Pages/details.aspx?data id $=37$

two important novelties. First, it established a required public accounting system of managing entities and common services in employers' mutuals. This led to both greater transparency of their accounts and state facility for auditing. Second, workers' representatives were, for the first time, incorporated into the governing bodies of these mutuals (i.e., management boards, general assemblies, and special benefits committees). In 1976, with the transition to democracy in process, Spain signed the International Covenant on Civil and Political Rights. In 1977, compulsory membership in Falange's vertical "union” was endedremember, it was the only "union" permitted throughout the dictatorship—and trade unions were legally established. Political parties were also legalized. The Spanish Constitution, approved in 1978, officially incorporated this new democratic reality. ${ }^{46}$ However, new unions had to deal with a wide variety of demands during an economic crisis with high inflation and unemployment, which led to workers' loss of purchasing power compared with their counterparts in Western Europe.

Furthermore, almost forty years of compulsory membership in the Falange "union" took its toll in terms of trade union culture in the democratic stage. ${ }^{47}$ Even with union freedom, in the late 1970s Spain had one the lowest rates of trade union membership of Western European countries (Table 4). With so many societal issues to address, little union pressure was brought to bear on the management of

46. BOE, November 18, 1978, no. 276, 26246-9. For more on labor reforms during the transition to democracy, see Vilar-Rodríguez, "El trabajo."

47. In this regard, there is literature that studies the importance of strong unions in the development of Social Security legislation that looks after workers' interests. See, for example, Van Leewen, “Trade Unions.” 
industrial accident insurance by the mutuals. Moreover, there were delays in enacting the comprehensive and in-depth analysis of issues affecting the Social Security system (published in Libro Blanco de la Seguridad Social [White Paper on Social Security] in 1977). Instead, temporary remedies and stop-gap solutions were introduced to deal with the problems. ${ }^{48}$

The old structures inherited from a long dictatorship ultimately determined the social policy model in the new Spanish democracy. ${ }^{49}$ In fact, in Francoist Spain, public social expenditures did not receive the monies necessary because of the traditional tax system and the priority given to balancing the budget, which made it impossible to guarantee access to social coverage equivalent to other Western European countries. As Comín Comín points out, "the regime tried to patch up the system introduced by the Basic Law of 1963, via the Social Security laws of 1972 and 1974. But the situation did not improve." 50 The Law on the Financing and Improvement of the Protective Action of the General Social Security Scheme, mentioned earlier, offered few improvements, even though the introduction to this law affirmed the desire of the Spanish political class to establish new "criteria generally adopted by the Social Security systems of the countries integrated into the European Economic Community." 51 It was necessary to wait until the transition to democracy in 1977, when Fernández Ordoñez's eagerly awaited tax reform was approved, and it modernized the Spanish fiscal system. In the same year, it was agreed that the state contribution to finance the Social Security would be increased by 20 percent of its previous budget.

In 1978, rather than opting for full direct state management, the state shared this function with distinct legal entities. Public management of the Social Security administration would predominate, yet private managers were allowed to collaborate in two ways: as mutuals or as individual employers. Thus, employers' industrial accident mutuals affected the Social Security model within the new democratic framework. ${ }^{52}$

48. To read more on the historical stages of Social Security development in Spain in the twentieth century, see Comín Comín, "Las fases históricas," 641-694.

49. For further details, see Vilar-Rodríguez and Pons-Pons, "La Ley de Bases de la Seguridad Social,” 145.

50. See Comín Comín, "Los seguros sociales."

51. See Comín Comín, "Las fases históricas."

52. In particular, Article 2.3 of Royal Decree-Law 38/1978, of November 18, on institutional management of Social Security, Health and Employment: "the present collaboration in the management may be continued by Companies, Employers' Mutuals and Public and Private Associations, Foundations and Entities, subject to prior registration in a Public Register.” BOE, November 18, 1978, no. 276, 26246-9. 
Also in 1978, a single fund designated for the entire Social Security system was introduced via the Tesorería General de la Seguridad Social (General Treasury for Social Security; TGSS), under the principle of financial solidarity. ${ }^{53}$ The premiums for industrial accident insurance, which had been Social Security contributions since 1972, were included within this single fund. However, an important change was introduced in 1979: the TGSS assumed responsibility for the collection of these contributions and transferred the corresponding amount to the employers' mutuals every month. This was new, because previously the mutuals' deducted their contributions to the Common and Social Services of the Social Security. ${ }^{54}$ This measure, in which the TGSS now collected the contributions of the employers associated with the mutuals, had a major impact on the mutuals' financial and accounting. A further step in this process came in 1980, when the property and assets of the mutuals were differentiated into two lots. ${ }^{55}$ In one lot, the mutuals' movable and immovable property related to industrial accident premiums became part of the patrimonio único (exclusive assets) of Social Security, under the ownership and administration of the TGSS. In the second lot, the mutuals' historically accumulated property continued to be administered according to the statutes of each mutual.

To incorporate all these changes, in 1984 a new general regulation was passed: On the Collaboration of Employers' Industrial Accident Mutuals in the Management of Social Security. ${ }^{56}$ This new regulation was designed to ensure that mutuals were transparent in their dealings with the Social Security system. This legislation expanded the state's auditing and oversight of the mutuals' property and assets and addressed basic issues (i.e., mutuals' payments to the administration, establishment of statutory deposits, and updating of administrative expenses and reserves). A period of three months was given for mutuals to separate their properties by ownership, and the resulting accounts had to be sent to the TGSS. Additionally, any excesses in administrative expenses and any financial penalties imposed on the employers' mutuals had to be paid out of a mutual's voluntary reserves or assets. Employers' mutuals' administrative expenses were generally in excess of 10 percent of their total revenues, which was a violation of the

53. BOE, November 18, 1978, no. 276, 26246-9.

54. By Royal Decree 1245/1979, of May 25, Article 2.1, BOE, May 29, 1979, no. $128,11845-6$.

55. By Royal Decree 255/1980, of February 1, BOE, February 12, 1980, no. $37,3340-1$.

56. Order of April 22, 1984, On the Collaboration of Employers' Industrial Accident Mutuals in the Social Security System, BOE, April 12, 1984, no. $88,10414-6$. 
Table 5. Contributions and administrative expenses of the employers' mutuals, 1966-1986

\begin{tabular}{|c|c|c|c|}
\hline Year & $\begin{array}{r}\text { Contributions } \\
\text { (millions of } \\
\text { pesetas) }\end{array}$ & $\begin{array}{r}\text { Administrative } \\
\text { Expenses (millions } \\
\text { of pesetas) }\end{array}$ & $\begin{array}{r}\text { Administrative } \\
\text { Expenses as \% } \\
\text { of Contributions }\end{array}$ \\
\hline 1966 & $8,920.73$ & $1,226.4$ & 13.75 \\
\hline 1967 & $9,168.42$ & $1,017.0$ & 11.09 \\
\hline 1968 & $9,185.37$ & 961.3 & 10.47 \\
\hline 1969 & $10,831.91$ & $1,030.8$ & 9.52 \\
\hline 1970 & $12,399.70$ & $1,146.7$ & 9.25 \\
\hline 1971 & $14,323.13$ & $1,266.7$ & 8.84 \\
\hline 1972 & $17,145.76$ & $1,461.4$ & 8.52 \\
\hline 1973 & $21,230.34$ & $1,661.7$ & 7.83 \\
\hline 1974 & - & $1,995.3$ & n.a. \\
\hline 1975 & - & $3,090.3$ & n.a. \\
\hline 1976 & $36,318.7$ & $3,920.2$ & 10.79 \\
\hline 1977 & $46,939.6$ & $4,882.8$ & 10.40 \\
\hline 1978 & $59,540.7$ & $5,927.2$ & 9.95 \\
\hline 1979 & $68,311.0$ & - & n.a. \\
\hline 1980 & $81,038.0$ & - & n.a. \\
\hline 1981 & $86,297.0$ & $9,182.0$ & 10.64 \\
\hline 1982 & $97,822.0$ & $10,396.0$ & 10.63 \\
\hline 1983 & $115,043.0$ & $11,632.0$ & 10.11 \\
\hline 1984 & $121,590.0$ & $12,982.0$ & 10.68 \\
\hline 1985 & $120,747.3$ & $13,819.0$ & 11.44 \\
\hline 1986 & $142,154.0$ & $15,276.0$ & 10.75 \\
\hline
\end{tabular}

Source: Authors' compilations. For 1969-1973 contributions, see números extraordinarios de estadística 1974 (extra numbers with statistical data 1974), 12, Revista del Sindicato Nacional del Seguro. For 1966-1975 administrative expenses, see datos de las cuentas de gestión de las Mutualidades Laborales y las Mutuas Patronales (data from the management accounts of the Labor Mutualities and the Employers' Mutual Societies), Ministerio de Trabajo, Libro Blanco, 447-449. All three columns for 1975-1986 are from Ministerio de Trabajo y Seguridad Social (Ministry of Labor and Social Security), Memoria económico financiera de las Mutuas Patronales de Accidentes del Trabajo (Financial Economic Report of the Employers' Mutual), cited in Serrano and Colmenar, in Las Mutuas Patronales, 166.

established legal limits (Table 5). In some cases, this excess reached 114 percent of declared revenue. ${ }^{57}$

It seems clear that the legislative steps taken early in Spain's democracy were to reinforce the integration of the mutuals into the Social Security organizational scheme and to continue government supervision without affecting the mutuals' nature, organization, or functioning. However, legislation was not enough to achieve the expected results in terms of either greater transparency or more efficient management of these entities. The financial and accounting systems of some mutuals were so chaotic that the Ministry of Labor and Social Security implemented an audit plan in the early 1980s. These audits detected

57. These excesses were frequent, according to the data compiled by the Court of Auditors and the Labor Inspection Service. See Martín and Colmenar, Las Mutuas Patronales, 161. 
accounting and management irregularities in several employers' mutual, amounting to 185 million pesetas. For example, in September 1983 five employers' mutuals-El Fénix Mutuo, Mutua General Agropecuaria, El Porvenir, La Metalúrgica, and La Ibérica—were audited by the Ministry of Labor and Social Security. Some of these mutuals had been created in the 1930s and had a long history in Spain. Alleged fraud included wrongful receipt of unemployment insurance; falsification of medical reports; irregularities in the processing of disability claims; defrauding the Social Security system and private individuals in relation to the payment of contributions; and "systematic errors," including amounts of money from unknown origins and unauthorized deductions. ${ }^{58}$

Many smaller employers' mutuals went out of business because of the increase in state control of their property, assets, and accounts, and with the disappearance of some allowances or subsidies related to premiums. Even the establishment of rescue or reorganization plans to help with financial difficulties could not save them. The total number of mutuals rose to 162 in 1984 from fewer than 25 in 1976 (see Table 2), but by the end of 1987, after the first restructuring of the sector, the number fell to 130. Nearly all of the mutuals operating at the local or district level had disappeared, with only five remaining. Sixty-three surviving mutuals operated at the provincial level, while 36 were interprovincial, 19 were national (i.e., active in the 50 Spanish provinces and in two autonomous cities), and seven were regional. ${ }^{59}$ The state then promoted concentration at the start of the 1990s. ${ }^{60}$ There were only 97 employers' mutuals in January 1990, and 16 more disappeared that year. Twelve more were gone in 1991; 26 in 1992; and 16 in 1993, equaling a total of 70 fewer entities between 1990 and 1993 (see the Appendix). This reduction facilitated greater state control over the mutuals, improved the bookkeeping of mutuals' accounts, and allowed for better coordination of the needed services, care, and attention of protected workers. These changes took place after the aforementioned audit plan implemented by the Ministry of Labor in the early 1980s. The restructuring also changed the average scale of the industrial accident mutuals. In 1987, at the start of this restructuring process, the leading

58. Rodolfo Serrano, "Cinco mutuas patronales, intervenidas por el Ministerio de Trabajo al haberse detectado irregularidades contables," Hemeroteca El País, August 30, 1983, https://elpais.com/diario/1983/08/30/economia/431042402 850215.html.

59. These data come from Ministry of Labor and Social Security, Employers' Mutual Insurance Companies. Social Balance and Economic-Financial Report, 1987, MITRAMISS.

60. Law 4/1990 of June 29 on the General State Budget for 1990. BOE, June 30, 1990, no. 156, 18669-710. 
twenty mutuals accounted for 77.38 percent of total premiums; by 2006 just five of these mutuals accounted for 67 percent of premiums.

The mutuals did receive some recompense in return for greater state intervention. First, the prohibition on covering the risks of accidents of state companies and public agencies was removed (under the supposition that it was necessary for mutuals to make better use of their available resources). Second, their geographical scope was made wider, which facilitated mergers and fostered greater concentration of the sector. Thus, the minimum number of companies required to establish a mutual increased, along with the required number of workers needed to run operations. Specifically, the number rose from ten employers and two thousand workers per mutual to fifty employers and thirty thousand workers. Simultaneously, legislation modified the official name of employers' mutuals to Mutuas de Accidentes de Trabajo y Enfermedades Profesionales de la Seguridad Social (Mutual Insurance Companies of the Social Security for Work-related Accidents and Occupational Diseases). Moreover, as noted above, starting in 1990 the Ministry of Labor and Social Security tightened control over the mutuals through annual audits (carried out by the Office of the Comptroller General of the Social Security) and made it illegal for someone to hold a managerial or executive position in a mutual and also be on the board of directors of any associated company.

In the final decades of the twentieth century, the mutuals assumed greater power within Social Security. ${ }^{61}$ New legislation allowed employers belonging to a mutual for coverage of workers' industrial accidents and occupational diseases to manage the economic benefits of workers' temporary incapacity arising from common contingencies with the same entity. ${ }^{62}$ Here, common contingency refers a situation in which a worker-injured during an accident or diagnosed with a nonoccupational illness-is unable to work and receives health care from the Public Health System. The same entity refers to the same mutual. Likewise, the mutuals could also manage the economic benefits related to the temporary incapacity of self-employed workers and those employed under the special Social Security scheme for agricultural workers. These extensions were included in the new regulation on the collaboration of mutuals in the management of Social Security, approved by Royal Decree 1993/1995, December 7, 1995. This regulation combined previously incorporated key elements regarding the role of mutuals in the Social Security scheme and consolidated their

61. Law 22/1993, of December 19, on the General State Budget for 1994 and Law 42/1994 of December 30 on Fiscal, Administrative and Social Measures, BOE, December 31, 1994, no. 313, 39458-504.

62. For further comments in this respect, see Sempere, Hacia un nuevo modelo. 
Table 6. Workers protected against industrial accidents and occupational diseases, 1977-1999

\begin{tabular}{lrrrr}
\hline Year & $\begin{array}{r}\text { Total } \\
\text { Mutuals }\end{array}$ & $\begin{array}{r}\text { Total National Social } \\
\text { Security Institute }\end{array}$ & $\begin{array}{r}\text { Total } \\
\text { System }\end{array}$ & $\begin{array}{r}\text { Mutuals as \% of } \\
\text { total system }\end{array}$ \\
\hline 1977 & $3,294,617$ & $5,597,680$ & $8,889,297$ & 37.0 \\
1978 & $3,695,542$ & $5,222,028$ & $8,917,570$ & 41.4 \\
1979 & $3,839,286$ & $5,100,277$ & $8,939,563$ & 42.9 \\
1980 & $3,869,964$ & $5,120,142$ & $8,990,106$ & 43.0 \\
1981 & $4,858,140$ & $4,037,042$ & $8,895,182$ & 54.6 \\
1982 & $5,038,027$ & $3,040,498$ & $8,078,525$ & 62.4 \\
1983 & $5,163,521$ & $2,955,601$ & $8,119,122$ & 63.6 \\
1984 & $5,260,504$ & $2,598,100$ & $7,858,604$ & 66.9 \\
1985 & $5,690,053$ & $2,592,100$ & $8,282,153$ & 68.7 \\
1986 & $5,658,178$ & $2,417,227$ & $8,075,405$ & 70.1 \\
1987 & $6,582,736$ & $1,998,472$ & $8,581,208$ & 76.7 \\
1988 & $7,136,620$ & $2,081,709$ & $9,218,329$ & 77.4 \\
1989 & $7,710,477$ & $2,112,190$ & $9,822,667$ & 78.5 \\
1990 & $8,360,891$ & $1,869,142$ & $10,230,033$ & 81.7 \\
1991 & $8,961,028$ & $1,305,826$ & $10,266,854$ & 87.3 \\
1992 & $9,236,278$ & 681,169 & $9,917,447$ & 93.1 \\
1993 & $8,806,376$ & 791,663 & $9,598,039$ & 91.8 \\
1994 & $8,953,347$ & 761,932 & $9,717,279$ & 92.2 \\
1995 & $9,117,305$ & 743,149 & $9,860,454$ & 92.5 \\
1996 & $9,308,750$ & 756,424 & $10,065,174$ & 92.5 \\
1997 & $9,645,756$ & 874,965 & $10,520,721$ & 91.7 \\
1998 & $10,171,040$ & $1,029,683$ & $11,200,723$ & 90.8 \\
1999 & $10,900,000$ & 998,617 & $11,898,617$ & 91.6 \\
\hline$N 010: *$ & & & \\
\hline
\end{tabular}

Note: ${ }^{*}$ The National Social Security Institute (INSS) was formed after the former managing body, the National Welfare Institute, was eliminated in 1978. The INSS was a managing body of Social Security, with its own legal personality. It was associated with the Ministry of Inclusion, Social Security and Migration via the Secretariat of State for Social Security and Pensions. It was entrusted with a large segment of the management and administration of the economic benefits of the Social Security in Spain. Source: Authors' own preparation based on Valenzuela, Protagonistas, 41.

function via new competencies. ${ }^{63}$ Consequently, at the turn of the century, even as mergers and acquisitions continued, the mutuals had an active role in managing industrial accident and occupational disease insurance. From 1977 to 1987, the employers' industrial accident mutuals increased the number of workers protected against occupational risks as compared to other systems of protection (Table 6). In 1977, the mutuals protected 37 percent of the total number of workers insured by the system as a whole. ${ }^{64}$ By 1987 this had increased to 76 percent. This percentage continued rising over the following years, reaching 91.6 percent in 1999.

63. BOE, December 12, 1995, 296, 35584-613.

64. Valenzuela, Protagonistas, 41. 
The legislative changes made at the end of the twentieth century in relation to the mutuals have been widely questioned in the literature in two fundamental respects, especially by specialists in law: a lack of legislative clarity, and a lack of parliamentary debate on the role of the employers' mutuals within the Social Security system in Spain. With regard to the first point, criticism started with the "imprecision" of the official name they were given in Law 4/1990, on General State Budgets: Mutuas de Accidentes de Trabajo y Enfermedades Profesionales de la Seguridad Social. This designation omits the explicit term "employers" (although they are still employers' mutuals), and it only mentions some coverage (i.e., occupational diseases and temporary incapacity from common risks). At the same time it fails to make any reference to preventing occupational risks, which also falls within their competencies. ${ }^{65}$ Even after the frenzy of legislative changes passed in recent decades, there are aspects of the Mutual Insurance Companies of the Social Security for Work-related Accidents and Occupational Diseases that remain problematic. ${ }^{66}$ First, they are employers' associations that operate within the sphere of Social Security, but despite the name they are not part of the public structure as determined by the Law on the Prevention of Occupational Risks. Second, they not only manage occupational accidents and diseases but also common risks when these result in temporary incapacity. On the lack of parliamentary debate on the role of the employers' mutuals in Spain, García Jiménez has criticized the existence of an "overlapping and reiterative legislative framework that lacks rigor and is full of increasing legal complexity and uncertainty." ${ }^{67}$ Within this line of argument, Sempere has noted that the essential legislative changes concerning the role of the mutuals have taken place with "excessive haste, a total mix of matters and an absence of calm and measured debate." ${ }^{88}$ Consequently, this author concludes that the system has drifted toward a contradictory model in which, first, the privatization of the management of Social Security has been fostered (given that mutuals are private legal entities that acquired increasing powers), and second, these same entities have been made more public by increasing the supervision of their day-to-day management by the public authorities.

The many legislative actions passed in the first years of the twentyfirst century has strengthened both the role played by the mutuals in the current Social Security system and this contradictory model. These mutuals now carry out a multitude of functions while being

65. Sempere, "La incesante metamorfosis."

66. Also in line with Sempere, "La incesante metamorfosis," 10.

67. García Jiménez, Las mutuas, 133.

68. Sempere, "La incesante metamorfosis," 11. 
chameleon-like entities. ${ }^{69}$ It should be noted that while the legislation reinforces their key role in the system, new laws are always being written to improve their efficiency and increase oversight, although always respecting the mutuals' legal nature as private and employer-run.

\section{Conclusions}

The historical analysis of the industrial accident scheme in Spain provides an excellent case study to examine the role of employers in the development of social insurance in a context of limited pressure on wages and state institutions moving from a dictatorship to a democracy. Under such circumstances, this scheme's development in the Spanish case did not occur through alliances between workers and employers but rather between employers and the state. With the law that was passed in 1900, employers could assume minimal liability for compensating workers who had been hurt in accidents. Meanwhile, the employers controlled the compensation process, minimized their costs, and opposed an extension of insurance or coverage related to occupational diseases. This occurred because of the government's passivity and alignment with employers, and a working environment in which there was scant union pressure and 50 percent of workers were tied to agriculture, which had no insurance mutuals at all. The first biennium of the Second Republic saw the introduction of one key step: making insurance compulsory in both the agricultural and industrial sectors. The employers' quickly responded by creating more mutuals to control the scheme, keeping costs low, and sharing in substantial surpluses in the form of rebates at the end of each financial year. These mutuals coexisted with private insurance companies that also managed this type of risk, among other types of insurance. The outbreak of the Spanish Civil War and the Franco dictatorship reinforced employers' control of this social scheme. The state instituted greater bureaucratic control yet also guaranteed the mutuals' management of industrial insurance. This enabled the mutuals to keep their costs down, precluded them from having to treat occupational diseases, and guaranteed continued rebate payments.

The entry of technocrats into Franco's government and passage of the Basic Law in 1966, implementing Social Security, gave rise to tension between the mutuals and the state. After some months of uncertainty, the mutuals retained management of industrial accident

69. For more information on the reforms of mutuals at the beginning of the twenty-first century, see Molina, "La reforma," 265. 
insurance; while they now had no competition from private insurance companies, they also faced greater state control. The new regulations required oversight of the mutuals' property, assets, and accounts (and limited administrative expenses and rebates) and required they separate their accident insurance business from their other lines of insurance. The mutuals resisted these changes for as long as possible. The Law on Social Security Financing, passed in 1972, in the twilight of the dictatorship, added another step in the supervision of these entities. It introduced new legal requirements and transformed insurance premiums into Social Security contributions. These tighter regulations led to less fragmentation in the sector as many mutuals were liquidated or absorbed when they could not comply with the new requirements. The absence of class-based unions and democratic labor regulations made it possible for a model conceived before the dictatorship—and linked to private coverageto be concentrated under the control of employers and their mutual organizations and not incorporated into the Social Security system managed by the state. This was detrimental to workers in terms of health coverage and compensation in the event of accidents, especially with regard to inadequate prevention of occupational risks and insufficient rehabilitation of injured workers. The state institutions managing the Social Security had bureaucratic and formal control over the mutuals, but they did little to help workers because the oversight was too limited.

This model, cobbled together over much of the twentieth century, conditioned the management model for industrial accident insurance during Spain's democratic period starting in 1977. The battle was between the state and employers, instead of between employers and workers, because there were no free trade unions after almost forty years of dictatorship. The low unionization rate in the first years of the transition meant there was little pressure to change the management model of the industrial accident scheme under the control of employers' mutuals. The state increased its supervision of the mutuals, but the latter not only continued to manage the insurance business but also collaborated with the state on the Social Security system. The state intensified its auditing and control even as the mutuals consolidated their role in insurance and preserved their legal status as private enterprises. They even increased their role when a greater percentage of workers were covered by insurance (i.e., agricultural workers) and coverage was expanded to include common risks. Within this long process, actions by the state-to audit more effectively and to better utilize available resources-and the mutuals—to win business and reduce costs-eventually led to the current situation in which there are only nineteen employers' mutuals. 
Bibliography of Works Cited

Books

Babiano, José. Paternalismo industrial y disciplina fabril en España (19381958). Madrid: Consejo Económico y Social, 1998.

Bengoechea, Soledad. Patronal catalana, corporativismo y crisis política, 18981923. Barcelona: Universitat Autònoma de Barcelona, 1992.

Cabrera, Mercedes. El poder de los empresarios: política e intereses económicos en la España contemporánea (1875-2000). Madrid: Taurus, 2002.

Conferencia de Seguros Sociales. Conclusiones de la Ponencia del Seguro de Accidentes del Trabajo en la Agricultura. Madrid: Sobrinos Sucesora M. Minuesa de los Ríos, 1917.

Cuesta Bustillo, Josefina. Los seguros sociales en la España del siglo XX. La crisis de la Restauración. Madrid: Ministerio de Trabajo y seguridad Social, 1988.

Esping-Andersen, Gøsta. Three Worlds of Welfare Capitalism. Princeton, NJ: Princeton University Press, 1990.

Fábregas, Pere. Los primeros 100 años de Mutua Universal. Barcelona: Mutua Universal, 2007.

García Jiménez, Manuel. Las mutuas de accidentes de trabajo y enfermedades profesionales: gestión privada de la Seguridad Social. Córdoba: Universidad de Cordoba, 2012, https://helvia.uco.es/xmlui/handle/10396/6329.

Germán Zubero, Luis G., Enrique Llopis Agelán, Jordi Maluquer de Motes, and Santiago Zapata Blanco eds. Historia económica regional de España. Siglos XIX y XX. Barcelona: Crítica, 2001.

González Madrid, Damián A., and Manuel Ortiz Heras. El estado del bienestar entre el franquismo y la transición. Madrid: Silex, 2020.

Hernando de Larramendi,Ignacio. Así se hizo MAPFRE. Mi tiempo. Madrid: Actas Editorial, 2001.

Instituto de Reformas Sociales. Memoria General de la Inspección del Trabajo correspondiente año 1923. Madrid: Instituto Dirección General de Trabajo e Inspección, 1924.

Jordana de Pozas, Luis. La Caja Nacional de Seguro de Accidentes del Trabajo y sus primeros resultados. Madrid: INP, 1933.

Mares, Isabela. The Politics of Social Risk: Business and Welfare State Development. Cambridge: Cambridge University Press, 2003

Martín Serrano, Antonio, and Luis J. Colmenar. Las Mutuas Patronales. La gestión privada de la Seguridad Social. Madrid: Trivium, 1989.

Ministerio de Trabajo. Libro Blanco de la Seguridad Social. Madrid: Ministerio de Trabajo, 1977.

Montero García, Feliciano. Orígenes y antecedentes de la previsión social. Los seguros sociales en la España del siglo XX. Madrid: Ministerio de Trabajo y Seguridad Social, 1988.

Palacio Morena, Juan I. La institucionalización de la Reforma Social en España (1883-1924). La Comisión y el Instituto de Reformas Sociales. Madrid: Ministerio de Trabajo y Seguridad Social, 1988. 
Pons-Pons, Jerònia, and Javier Silvestre, eds. Los orígenes del Estado de Bienestar en España, 1900-1945: los seguros de accidentes, vejez, desempleo y enfermedad. Zaragoza: Prensas Universitarias de Zaragoza, 2010.

- El seguro de salud privado y público en España. Su análisis en perspectiva histórica. Zaragoza: Prensas Universitarias de Zaragoza, 2014.

Redecillas, Antonio. El mutualismo laboral como medio de protección social. Un estudio económico-financiero. Madrid: CES, 2011.

Samaniego Boneu, Mercedes. La unificación de los seguros sociales a debate. La Segunda República. Madrid: Ministerio de Trabajo y Seguridad Social, 1988.

Sempere Navarro, Antonio V. Hacia un nuevo modelo de gestión de la incapacidad temporal. Madrid: Ministerio de Trabajo y Asuntos Sociales, 2005.

Swenson, Peter A. Capitalists against Markets: The Making of Labor Markets and Welfare States in the United States and Sweden. Oxford: Oxford University Press, 2002.

Valenzuela de Quinta, Enrique. Protagonistas del Mutualismo de Accidentes de Trabajo. 100 años de historia (1900-2000). Madrid: Association of Industrial Accident Mutuals, 2000.

Wilensky Harold L., and Charles N. Lebeaux. Industrial Society and Welfare State. London: Macmillan, 1965.

\section{Articles and Chapters in Books}

Barrera, Carlos. "El Opus Dei y la prensa en el tardofranquismo." Historia y Política, no. 28 (2012): 139-165.

Comín Comín, Francisco. "Las fases históricas de la Seguridad Social en España del siglo XX." In Cien años de protección social en España, edited by José Luis Torturero, 641-694. Madrid: Ministerio de Trabajo y Seguridad Social, 2017.

— . "Los seguros sociales y el estado de bienestar en el siglo XX." In Los orígenes del Estado de Bienestar en España, 1900-1945: los seguros de accidentes, vejez, desempleo y enfermedad, edited by Jerònia Pons-Pons and Javier Silvestre, 17-50. Zaragoza: Prensas Universitarias de Zaragoza, 2010.

García Ruiz, José Luis, and Leonardo Caruana. "Historia de una mutua patronal durante el franquismo: MAPFRE Mutua Patronal (FREMAP), 1966-1975." TST, no. 22 (2012): 66-95.

Mares, Isabela. "The Sources of Business Interest in Social Insurance: Sectoral versus National Differences." World Politics 55, no. 2 (2003), 229-258.

Mares, Isabela. "Distributional Conflicts in Mature Welfare States." In Divide and Deal: The Politics of Distribution in Democracies, edited by Ian Shapiro, Peter A. Swenson, and Daniela Donno, 43-71. New York: NYU Press, 2008.

Molina Navarrete, Cristóbal. "La reforma en materia de mutuas de Accidentes de trabajo y enfermedades Profesionales: Modificaciones incesantes, Racionalización aplazada.” Temas Laborales, 112 (2011); 261-297.

Muñoz, Javier. "Después de la tormenta. Acción política y cultural de los intelectuales católicos entre 1956 y 1962." Historia y Política, no. 28 (2012): 83-108.

Philipsen, Niels J. "Industrial Accidents and Occupational Diseases: Some Empirical Findings for The Netherlands, Belgium, Germany and Great 
Britain.” In Industrial Accidents and Occupational Diseases: Some Empirical Findings for the Netherlands, Belgium, Germany \& Great Britain, edited by Ton Hartlief and Saskia Klosse, 159-196. New York: Springer Verlag Publisher, 2007.

Pons-Pons, Jerònia. "Employers and Industrial Accident Insurance in Spain, 1900-1963." In The Appeal of Insurance, coordinated by Geoffrey Clark, Gregory Anderson, Christian Thomann, and J. Matthias Graf von der Schulenburg, 201-225. Toronto: University of Toronto, 2010.

_ - "La gestión patronal del seguro obligatorio de accidentes de trabajo durante el franquismo (1940-1975)." Revista de Historia Industrial, 45 (2011): 109-144.

Porras, M. Isabel. "La medicina y los seguros en el abordaje del problema de los inválidos del trabajo en España en la primera mitad del siglo XX.” História, Ciências, Saúde-Manguinhos 13, no. 2 (2006), 393-410.

Prat, Marc, and Óscar Molina. "State Corporatism and Democratic Industrial Relations in Spain 1926-1935: A Reappraisal.” Labor History 55, no. 2 (2014): 208-227.

Sánchez López, Rosario, and Encarna Nicolás Marín. "Sindicalismo vertical franquista: la institucionalización de una antinomia (1939-1977)." In Historia de Comisiones Obreras (1958-1988), edited by David Ruiz, 13-17. Madrid: Siglo XXI, 1993.

Sánchez Recio, Glicerio. "El franquismo como red de intereses.” In Los empresarios de Franco: Política y economía en España, 1936-1957, coordinated by Glicerio Sánchez Recio and Julio Tascón, 13-22. Barcelona: Crítica, 2003.

Sempere Navarro, Antonio V. "La incesante metamorfosis de las mutuas patronales: ideas para el estudio." Tribuna Social: Revista de seguridad social y laboral 100 (1999): 9-21.

Silvestre Rodríguez, Javier. "Wage Compensation for Workplace Disamenities during Industrialization: The Case of Spain, 1909-1920." Labor History 47 (2006): 43-72.

— . "Workplace Accidents and Early Safety Policies in Spain, 1900-1932." Social History of Medicine 21 (2008): 67-86.

Silvestre Rodríguez, Javier, and Jerònia Pons-Pons. "El seguro de accidentes del trabajo, 1900-1935. El alcance de las indemnizaciones, la asistencia sanitaria y la prevención." In Los orígenes del Estado de Bienestar en España, 19001945: los seguros de accidentes, vejez, desempleo y enfermedad, edited by Jerònia Pons-Pons and Javier Silvestre, 123-150. Zaragoza: Prensas Universitarias de Zaragoza, 2010.

Swenson, Peter A. "Good Distribution, Bad Delivery, and Ugly Politics: The Traumatic Beginnings of Germany's Health Care System.” In Divide and Deal: The Politics of Distribution in Democracies, edited by Ian Shapiro, Peter A. Swenson, and Daniela Donno, 245-79. New York: NYU Press, 2008.

Van Leeuwen, Marco H. D. "Trade Unions and the Provision of Welfare in the Netherlands, 1910-1960.” Economic History Review 50 (1997): 764-791.

Velarde, Juan, Antonio de Guindos, and Mariano Lázaro. "Aspectos Estadísticos del Seguro de accidentes de trabajo en España.” Revista de Trabajo 4 (1963): 9-46. 
Vilar-Rodríguez, Margarita. "El trabajo como pieza clave del puzle de la economía española: algunas reflexiones desde la historia económica (1939-2016). Historia, Trabajo y Sociedad 8 (2017): 35-63.

Vilar-Rodríguez, Margarita, and Jerònia Pons-Pons. "La Ley de Bases de la Seguridad Social de 1963: ¿una oportunidad perdida?” In El estado del bienestar entre el franquismo y la transición, edited by A. Damián, González Madrid, and Manuel Ortiz Heras, 125-156. Madrid: Silex, 2020.

Newspapers and Yearbooks

Anuario Guía del asegurador

Hemeroteca El País

Revista del Sindicato Nacional del Seguro

\section{Archives}

Archivo de Mutua General de Seguros, Madrid.

Archivo del Instituto Nacional de Gestión Sanitaria, Ministerio de Sanidad, Madrid, http://www.ingesa.mscbs.gob.es/

Archivo del Ministerio de Trabajo, Migraciones y Seguridad Social de España (MITRAMISS), Madrid, http://www.mitramiss.gob.es/ 
Appendix: Concentration of employers“ industrial accident mutuals, 1980-2019

\begin{tabular}{|c|c|c|}
\hline Entity registered with Ministry of Labor (year) & $\begin{array}{c}\text { Resulting merger or acquisition } \\
\text { (year) }\end{array}$ & Merger/acquisition (year) \\
\hline \multirow[t]{11}{*}{ 1. MCMUTUAL Barcelona (2006) } & \multirow[t]{9}{*}{ 126. Mutual Cyclops } & 001. ${ }^{+}$Previsión-Equidad (1993). Previously called Equidad (1988) \\
\hline & & $\begin{array}{l}\text { 005. Mutua Catalana de Accidentes (1989). Previously called } \\
\text { Asociación Vilmar (1986) }\end{array}$ \\
\hline & & $\begin{array}{l}\text { 027. Mutua Hoste (1993). Result of the merger of Vinos y } \\
\text { Aguardientes and Pescadores "a la parte" de Vizcaya (1992) }\end{array}$ \\
\hline & & 084. Mutua Panadera (A.S.P.A.) (1985) \\
\hline & & 097. Mutua Panadera (1985) \\
\hline & & 157. Alianza de Previsión Social (1986) \\
\hline & & 184. Metalúrgica de Levante (1990) \\
\hline & & 186. Mutua Pesquera de Vigo (1983) \\
\hline & & 194. Mutua Ntra. Sra. Del Carme (1992) \\
\hline & \multirow[t]{2}{*}{ 004. Midat Mutua } & 102. La Metalúrgica (1992) \\
\hline & & 260. COPA (1993). Previously called Rio Magro (1991) \\
\hline \multirow{3}{*}{ 2. MUTALIA Bilbao (2007) } & \multicolumn{2}{|l|}{ 002. Mutua Previsora } \\
\hline & $\begin{array}{l}\text { 020. Mutua Vizcaya Industrial } \\
\text { (2006) }\end{array}$ & 083. Comercial \\
\hline & 48. Pakea (2006) & 033. Mutua La Guipuzcoana (1977) \\
\hline
\end{tabular}


(Continued)

\begin{tabular}{|c|c|c|c|}
\hline \multirow[t]{12}{*}{$\begin{array}{l}\text { 3. ACTIVA MUTUA } \\
(2008)^{*}\end{array}$} & \multirow[t]{9}{*}{$\begin{array}{l}\text { REDDISMATT Tarragona } \\
(2007)\end{array}$} & \multirow[t]{3}{*}{ 019. Reddis-Unión Mutual } & $\begin{array}{l}\text { 003. Reddismat (1988). Result of the merger of Mutua Cerrajera } \\
\text { (1995) and USIL (1986) }\end{array}$ \\
\hline & & & 109. Patronos Tocineros (1985) \\
\hline & & & 226. Mutua Aseguradora del campo (1989) \\
\hline & & \multirow[t]{6}{*}{ 038. MATT } & $\begin{array}{l}\text { 014. Mutua del Centro de carpinteros Matriculados de Barcelona } \\
\text { (1987) }\end{array}$ \\
\hline & & & $\begin{array}{l}\text { 186. Mutua Comarcal contra Accidentes del trabajo en el ramo } \\
\text { construcción (1992) }\end{array}$ \\
\hline & & & $\begin{array}{l}\text { 202. Mutua Agrícola de la comarca de Tortosa (1992). Previously } \\
\text { called Mutualidad Roquetense de seguros contra acc. De trabajo } \\
\text { agrícola }\end{array}$ \\
\hline & & & 213. Mutua Patronal arrocera de Acc. Trab. Agricultura (1991) \\
\hline & & & 215. Mutua Patronal Agrícola d'Amposta (1990) \\
\hline & & & 234. Mutua Bisbalenca contra accidents de treball (1993) \\
\hline & \multirow[t]{2}{*}{ 25.MUPA Lleida (1993) } & \multicolumn{2}{|l|}{ 025. Mutua Lleiditana } \\
\hline & & \multicolumn{2}{|l|}{ 028. Mutua Igualadina } \\
\hline & 35. FIMAC Barcelona & \multicolumn{2}{|l|}{ 245. Seguros Porvenir (1982) } \\
\hline
\end{tabular}

(Continued) 
(Continued)

\begin{tabular}{|c|c|c|}
\hline \multirow[t]{6}{*}{ 7. MUTUA MONTAÑESA Santander } & \multicolumn{2}{|c|}{ 069. La Providencia (1993) } \\
\hline & \multicolumn{2}{|c|}{ 105. Mutua Harinera (1990) } \\
\hline & \multicolumn{2}{|c|}{188 Mutua Gerundense de Acc. De trab. (1990) } \\
\hline & \multicolumn{2}{|c|}{ 203. Mutua Agraria Abulense (1986) } \\
\hline & 204. Palentina (1984) & $\begin{array}{l}\text { 212. Mutualidad Prov. Agraria de Palencia. Previously called } \\
\text { Mutualidad de Patronos Agrícolas de la comarca de frechilla de } \\
\text { Campos }\end{array}$ \\
\hline & \multicolumn{2}{|c|}{ 265. Mutua Patronal del Oeste (1991) } \\
\hline \multirow[t]{5}{*}{ 10. MUTUA UNIVERSAL Barcelona } & \multicolumn{2}{|c|}{ 008. Mutua Asturiana de Accidentes (1989) } \\
\hline & \multicolumn{2}{|c|}{ 031. Mutua del Penedés y Barcelona (1986). Previously called Mutua Patronal de Barcelona } \\
\hline & \multicolumn{2}{|c|}{ 087. Mutua de las Fabricas de explosivos, productos químicos y minas (1989) } \\
\hline & \multicolumn{2}{|c|}{ 193. Leonesa de la Industria y del comercio (1989) } \\
\hline & \multicolumn{2}{|c|}{ 254. Mutua Patronal de Accidentes de trabajo de Béjar } \\
\hline \multirow[t]{7}{*}{ 11. MAZ Zaragoza } & \multicolumn{2}{|c|}{ 044. Comercial Aragonesa (1986) } \\
\hline & \multicolumn{2}{|c|}{ 046. Mutua Ilicitana (1996) } \\
\hline & \multicolumn{2}{|c|}{ 129. Mutua de la Industria y Comercio de Aragón (1991) } \\
\hline & \multicolumn{2}{|l|}{ 139. MUSAP (1993) } \\
\hline & \multicolumn{2}{|c|}{ 152. Mutual Flequera de Catalunya (1993) } \\
\hline & \multicolumn{2}{|c|}{ 181. Mutua Panadera de Zaragoza y Prov.(1988) } \\
\hline & \multicolumn{2}{|c|}{ 251. Guadalquivir-Costa del Sol (1994). Previously called Costal del Sol (1988) } \\
\hline
\end{tabular}


(Continued)

\begin{tabular}{|c|c|c|}
\hline \multirow[t]{9}{*}{ 15. UMIVALE Valencia (2006) } & \multirow[t]{5}{*}{ 015. MUVALE } & $\begin{array}{l}\text { 107. Levante Mediterránea (1993). Result of the merger of Mutua } \\
\text { sobre Acc. De trab. De la industria panadera provincia de Valencia } \\
\text { (1992), M de la sociedad de Maestros y patrones carpinteros de } \\
\text { Valencia (1992), and Unión Mediterránea (1991) }\end{array}$ \\
\hline & & 198. La Alianza (1990) \\
\hline & & 219. Mutua Patronal Accidentes de trabajo de Sueca (1990) \\
\hline & & 221. Mutua Agraria Valenciana (1992) \\
\hline & & 248. Mutua Patronal de Plateros, joyeros, orfebres (1992) \\
\hline & \multirow[t]{4}{*}{ 271. UNION MUSEBA-IBESVICO } & $\begin{array}{l}\text { 009. LABMAR (1995). Result of the merger of La Alianza Mataronense } \\
\text { (1992) and LABORUM (1994) }\end{array}$ \\
\hline & & 037. Unión Mutua (1994) \\
\hline & & $\begin{array}{l}\text { 104. MUSEBA, Mutua de Banca (1992). Previously called Mutua } \\
\text { Perpetuo Socorro (1985) }\end{array}$ \\
\hline & & 106. IBEVISCO (1992) \\
\hline
\end{tabular}

(Continued) 
(Continued)

\begin{tabular}{|c|c|c|}
\hline 21. MUTUA NAVARRA Pamplona & \multicolumn{2}{|c|}{ 199. Caja Navarra contra Accidentes Agropecuarios (1992) } \\
\hline \multirow[t]{4}{*}{ 39. Mutua Intercomarcal Barcelona (1993) } & \multirow[t]{3}{*}{ 098. Mutua Manresana } & 089. Mutua de Tárrega (1985) \\
\hline & & $\begin{array}{l}\text { 137. Mutualidad de Patronos del Ramo de la madera de Manresa } \\
\text { (1963) }\end{array}$ \\
\hline & & $\begin{array}{l}\text { 177. MAPA (1991). Previously called Asistencia y Previsión IBERIA } \\
\text { (1980) }\end{array}$ \\
\hline & \multicolumn{2}{|c|}{ 261. Mutua d'Accidents de treball del Valles } \\
\hline \multirow[t]{8}{*}{ 61. FREMAP Madrid } & \multicolumn{2}{|c|}{ 042. Mutua Empresarial Catalana (1984) } \\
\hline & \multicolumn{2}{|c|}{ 062. Mutua General Agropecuaria (1989) } \\
\hline & 081. Jucar (1989) & 200. La Arrocera, Mutua de Accidentes de trabajo \\
\hline & \multicolumn{2}{|c|}{ 082. Carbonera del Norte (1986) } \\
\hline & \multicolumn{2}{|c|}{ 086. Mutua Pesquera de Vigo (1983) } \\
\hline & \multicolumn{2}{|l|}{ 117. Regional Gallega } \\
\hline & \multicolumn{2}{|l|}{ 120. La Segoviana (1985) } \\
\hline & \multicolumn{2}{|c|}{ 146. Mutua de Brurriana (1988) } \\
\hline
\end{tabular}


(Continued)

\begin{tabular}{|c|c|c|}
\hline \multirow[t]{6}{*}{ 72. SOLIMAT Toledo (1997) } & \multicolumn{2}{|l|}{ 072. Soliss } \\
\hline & \multicolumn{2}{|l|}{ UMAP (1992) } \\
\hline & \multicolumn{2}{|c|}{ 12. Artes del Libro (1992) } \\
\hline & \multicolumn{2}{|c|}{ 170. Madrileña de Taxis (1992) } \\
\hline & \multicolumn{2}{|c|}{ 51. Mutua Gremio de Carbonerías de Madrid (1993) } \\
\hline & \multicolumn{2}{|c|}{ 113. Mutua Industrial y Mercantil de Ávila (1993) } \\
\hline 115. CESMA Ceuta & \multicolumn{2}{|c|}{ Mutua de Ceuta. Previously called denominada S.M.A.T. (1991) } \\
\hline \multirow[t]{7}{*}{ 151. ASEPEYO Barcelona } & \multicolumn{2}{|c|}{ 070. Mutua San Fermín (1986) } \\
\hline & \multicolumn{2}{|c|}{ 141. Mutua Melillense (1987) } \\
\hline & \multicolumn{2}{|l|}{ 153. Ibérica (1985) } \\
\hline & \multicolumn{2}{|c|}{ 160. AMICAL, Mutua patronal accidentes Menoría (1992) } \\
\hline & 163. Catalunya (1995) & $\begin{array}{l}\text { 060. Mutua de Accidentes en hoteles, cafés, restaurantes y similares } \\
\text { (A.H.C.R.Y.S.) (1986) }\end{array}$ \\
\hline & \multicolumn{2}{|c|}{ 180. Mutua Industrial y comarcal Accidentes de Trabajo (1984) } \\
\hline & \multicolumn{2}{|c|}{ 197. Mutua Mineros Industria Leonesa (1984) } \\
\hline
\end{tabular}

(Continued) 
(Continued)

\begin{tabular}{|c|c|c|}
\hline \multirow[t]{4}{*}{ 183. MUTUA BALEAR Palma de Mallorca } & \multicolumn{2}{|c|}{ 095. Mutua Felanigense (1991) } \\
\hline & \multicolumn{2}{|c|}{ 121. Mutua de Seguros de Llucmajor } \\
\hline & \multicolumn{2}{|c|}{ 125. Mutua Guanarteme (1996) } \\
\hline & \multicolumn{2}{|c|}{ 209. Mutua de Accidentes Agrícolas Balear } \\
\hline \multirow[t]{9}{*}{ 267. Unión de Mutuas UNIMAT Castellón (1990) } & \multicolumn{2}{|c|}{ 108. Mutua Patronal Sergobina } \\
\hline & \multicolumn{2}{|c|}{ 195. MUPATCHE, Mutua Patronal de Cheste } \\
\hline & \multicolumn{2}{|c|}{ 214. Unión gremial valentina } \\
\hline & $\begin{array}{l}\text { 236. Mutua Industrial } \\
\text { Castellonense }\end{array}$ & $\begin{array}{l}\text { 239. Mutua Patronal Accidentes Trabajo en agricultura Villareal de los } \\
\text { Infantes (1989) }\end{array}$ \\
\hline & \multirow[t]{3}{*}{ 242. Mutua de Azulejeros } & 165. Manises (1986) \\
\hline & & 182. La Senyera (1985) \\
\hline & & 196. AMAT (1986) \\
\hline & \multicolumn{2}{|c|}{ 252. Unión de empresas industriales } \\
\hline & \multicolumn{2}{|c|}{ 256. Mutua Patronal Saguntina } \\
\hline \multirow[t]{2}{*}{ 272. MAC Santa Cruz de Tenerife (1992) } & \multicolumn{2}{|l|}{ 079. Unión Tinerfeña } \\
\hline & \multicolumn{2}{|l|}{ 207. MUPATE } \\
\hline
\end{tabular}


(Continued)

\begin{tabular}{|c|c|c|c|}
\hline \multirow{16}{*}{$\begin{array}{l}\text { IBER-MUTAMUR Madrid } \\
\text { Merger Ibermutua and Mutuamur (1997) } \\
\text { Merger with Mutua Gallega }(2018)^{* *}\end{array}$} & \multirow[t]{8}{*}{ 273. Ibermutua } & \multicolumn{2}{|l|}{ 158. Castilla (1995) } \\
\hline & & \multirow[t]{2}{*}{ 268. MUP (1993) } & 047. Mutua del Puerto de Valencia (1991) \\
\hline & & & 114. MUP (1991) \\
\hline & & \multirow{5}{*}{$\begin{array}{l}\text { 270. Fénix Castellana } \\
\text { (1993) }\end{array}$} & 032. Mutua Castellana (1992) \\
\hline & & & 091. Mutua Granadina (1992) \\
\hline & & & 140. El Fénix Mutuo (1992) \\
\hline & & & 167. Asistencia Médica (1992) \\
\hline & & & $\begin{array}{l}\text { 249. Asociación Andaluza de Acc. de } \\
\text { Taxis (1992) }\end{array}$ \\
\hline & \multirow[t]{3}{*}{ 244. Mutuamur } & \multicolumn{2}{|l|}{ 073. La Legal (1991) } \\
\hline & & \multicolumn{2}{|c|}{ 161. Panadera Industrial y Comercial Prov. Murcia (1974) } \\
\hline & & \multicolumn{2}{|c|}{ 253. Mutua Sevillana de construcciones y obras (1983) } \\
\hline & \multirow[t]{3}{*}{ 263. Madin (2002) } & \multicolumn{2}{|c|}{ 068. Empresarios minero e industriales asturianos } \\
\hline & & \multicolumn{2}{|c|}{ 162. Mutua General Panadera } \\
\hline & & \multicolumn{2}{|l|}{ 179. Madin } \\
\hline & \multirow{2}{*}{$\begin{array}{l}201 \text { Mutua Gallega. La Coruña } \\
\text { (2018) }\end{array}$} & \multicolumn{2}{|l|}{ 018. La Naviera (1993) } \\
\hline & & \multicolumn{2}{|c|}{ 257. Mutua Patronal Coruñesa (1986) } \\
\hline
\end{tabular}

(Continued) 
(Continued)

\begin{tabular}{|c|c|c|}
\hline \multirow[t]{15}{*}{ 275. FRATENIDAD-MUPRESPA Madrid (1999) } & \multirow[t]{15}{*}{ 166. LA FRATERNIDAD } & 013. La Única, mutua filantrópico (1990) \\
\hline & & 040. Federación Madrileña industrias de carnes (1990) \\
\hline & & 057. Mutua de Industrias minero-metalúrgicas (1988) \\
\hline & & 065. Mutua Almanseña (1988) \\
\hline & & 066. MUDESPA (1991) \\
\hline & & 093. La Seguridad Mutua (1985) \\
\hline & & 123. PACI, Mutua General industrial y agrícola (1960) \\
\hline & & 127. M.E.M.I. Mutua empresas mineras e industriales (1987) \\
\hline & & 134. GUREARTE (1992) \\
\hline & & 156. Mutua Española de Previsión (1983) \\
\hline & & 185. Mutua Cerealista de Cáceres (1990) \\
\hline & & $\begin{array}{l}\text { 222. Mutua Rural (1993). Previously called Mutua Provincial Agraria e } \\
\text { Industrial de Burgos }\end{array}$ \\
\hline & & 240. La mecánica (1990) \\
\hline & & 255. Barcino Industrial y Comercial (1989) \\
\hline & & 259. Mutua de Accidentes Azucareros (1989) \\
\hline
\end{tabular}


(Continued)

\begin{tabular}{|l|l|l|}
\hline \multirow{2}{*}{$\begin{array}{l}\text { 269. MUPRESPA-MUPAG- } \\
\text { PREVISIÓN }\end{array}$} & 045. Mutua Patronal de las Industrial del pescado y derivados (1992) \\
\cline { 3 - 3 } & & 103. Mutua de Fabricantes de Papel (1985). \\
\cline { 3 - 3 } & & 217. PELAYO (1987) \\
\cline { 2 - 3 } & & 266. Asociación Mutual Industrial A.M.I. (1993) \\
\hline \multirow{2}{*}{ 276. EGARSAT (2007) } & 16. S.A.T & \\
\cline { 2 - 3 } & 085. Mutua Egara (1985) \\
\hline
\end{tabular}

Note:

${ }^{+}$Official registration number assigned by the Ministry of Labor.

BOE (Official State Gazette) No. 56, March 5, 2008, p. 13518.

** BOE No. 1, 1 January 1, 2019, pp. 134-135.

The names of the entities and localities are exactly as they appear in the original list.

The employers' industrial accident mutuals in bold were in existence as of December 31, 2019.

Source: Authors' preparation based on Associació Catalana De Mútues d'accidents de Treball (Catalan Association of Employers' Industrial Accident Mutuals), http://www.acmat.org/dir1.htm (last consulted on December, 2019). 